\title{
PEMBELAJARAN MODELTEAM ASSISTED INDIVIDUALIZATION (TAI) BERBANTUAN MODUL UNTUK MENINGKATKAN INTERAKSI SOSIAL DAN PRESTASI BELAJAR SISWA PADA MATERI REDOKS KELAS X.9 SMA MUHAMMADIYAH 1 KARANGANYAR TAHUN PELAJARAN 2015/2016
}

\author{
Nailil Maghfiroh, Widiastuti Agustina Eko Setyowati ${ }^{*}$, dan Haryono \\ Program Studi Pendidikan Kimia, FKIP Universitas Sebelas Maret, Surakarta, Indonesia
}

*Keperluan korespondensi, tel/fax: +6281280660500, email: widi_greco@yahoo.com

\begin{abstract}
ABSTRAK
Penelitian ini bertujuan untuk meningkatkan: (1) interaksi sosial pada materi pokok redoks siswa kelas X.9 SMA Muhammadiyah 1 Karanganyar dengan menggunakan model pembelajaran Team Assisted Individualization (TAI) berbantuan modul, dan (2) prestasi belajar pada materi pokok redoks siswa kelas X.9 SMA Muhammadiyah 1 Karanganyar dengan menggunakan model pembelajaran Team Assisted Individualization (TAI) berbantuan modul. Penelitian ini merupakan penelitian tindakan kelas yang terdiri dari dua siklus. Setiap siklus terdiri dari perencanaan tindakan, pelaksanaan tindakan, observasi, dan refleksi. Subjek penelitian adalah siswa kelas X.9 SMA Muhammadiyah 1 Karanganyar Tahun Pelajaran 2015/2016. Sumber data berasal dari guru dan siswa. Data diperoleh melalui angket, tes, observasi, serta wawancara. Teknik analisis data yang digunakan adalah analisis deskriptif kualitatif dan kuantitatif. Hasil penelitian menunjukkan bahwa pembelajaran model TAI berbantuan modul dapat meningkatkan: (1) interaksi sosial yang mengalami peningkatan dari $47,37 \%$ menjadi $71,05 \%$, dan (2) prestasi belajar aspek kognitif sebesar $34,21 \%$ meningkat menjadi $65,79 \%$. Sedangkan prestasi belajar aspek afektif pada siklus I telah mencapai target yaitu sebesar $81,58 \%$.
\end{abstract}

Kata Kunci : Team Assisted Individualization (TAI), Interaksi Sosial, Prestasi Belajar, Modul, Reaksi Redoks.

\section{PENDAHULUAN}

Pendidikan merupakan salah satu aspek penting dalam upaya peningkatan sumber daya manusia di Indonesia. Pengalaman di banyak negara menunjukkan, sumber daya manusia yang bermutu lebih penting daripada sumber daya alam yang melimpah. Sumber daya manusia yang berkualitas hanya dapat diwujudkan dengan pendidikan yang berkualitas. Menyadari pentingnya peningkatan kualitas sumber daya manusia, pemerintah terus berupaya melalui usaha mewujudkan pendidikan yang berkualitas [1].

Salah satu upaya pemerintah untuk meningkatkan mutu pendidikan adalah dengan melakukan perubahan kurikulum. Kurikulum merupakan bagian terpenting dalam pendidikan. Salah satu kurikulum yang digunakan pada sistem pembelajaran di Indonesia adalah Kurikulum Tingkat Satuan Pendidikan (KTSP). Menurut Badan Standar Nasional Pendidikan (BSNP) (2006), KTSP adalah kurikulum operasional yang disusun oleh dan dilaksanakan di masing-masing satuan pendidikan atau sekolah. Pada implementasi kurikulum ini, guru dituntut untuk mengembangkan kemampuan diri siswa sesuai dengan keunggulan ataupun keunikan dari setiap individunya. Pelaksanaan pengembangan diri dapat dilakukan dengan proses pembelajaran di kelas melalui berbagai pengalaman belajar yang inovatif, menantang, dan menyenangkan [2].

Dalam KTSP, kimia merupakan salah satu mata pelajaran yang diajarkan pada kurikulum SMA. Pembelajaran kimia di SMA bertujuan agar siswa memiliki kemampuan antara lain: (1) membangun kesadaran 
tentang keteraturan dan keindahan alam sebagai wujud kebesaran Tuhan Yang Maha Esa, (2) memupuk sikap ilmiah, (3) memperoleh pengalaman dalam menerapkan metode ilmiah melalui percobaan atau eksperimen, (4) meningkatkan kesadaran terhadap aplikasi ilmu kimia, (5) memahami konsep-konsep kimia dan saling keterkaitannya, (6) menerapkan konsep-konsep kimia untuk menyelesaikan masalah dalam kehidupan sehari-hari dan teknologi, (7) membentuk sikap positif terhadap kimia [3].

Perangkat pembelajaran yang digunakan di SMA Muhammadiyah 1 Karanganyar belum mengarah pada peningkatan ketertarikan siswa untuk mengikuti pembelajaran. Penyediaan media bagi guru untuk melangsungkan kegiatan belajar mengajar juga belum maksimal. Berdasarkan observasi yang dilaksanakan sebelum tindakan yaitu pada hari Selasa, 5 Januari 2016 menunjukkan bahwa pada pembelajaran di kelas, guru menyampaikan materi dengan metode ceramah dan siswa hanya mendengarkan. Selain itu, dalam menyampaikan materi, guru belum menggunakan media yang sesuai dengan karakteristik materi. Hal ini yang menyebabkan siswa menjadi kurang bersemangat dalam mengikuti kegiatan belajar mengajar dan menjadi kurang aktif.

Berdasarkan hasil wawancara dengan beberapa siswa kelas $X$ diperoleh bahwa pelajaran kimia merupakan pelajaran yang sulit. Mereka mengalami kesulitan karena kurang memahami konsep-konsep yang ada di dalamnya. Selain itu, beberapa siswa kesulitan dalam perhitungan dan hafalan. Ada juga yang mengungkapkan bahwa kimia bersifat abstrak. Menurut guru mata pelajaran kimia kelas $X$ diketahui bahwa di antara berbagai materi kelas $X$ semester genap, materi reaksi redoks (reduksi dan oksidasi) merupakan materi yang dianggap paling sulit. Reaksi redoks merupakan materi yang membutuhkan pemahaman konsep yang kuat. Apabila siswa kurang meguasai konsep yang ada, maka selanjutnya siswa akan mengalami kesulitan pada materi yang berhubungan dengan redoks karena materi kimia saling berkesinambungan. Materi redoks termasuk materi yang sulit karena untuk memahami materi tersebut siswa perlu memahami terlebih dahulu materi ikatan kimia dan tata nama senyawa kimia yang juga memerlukan pemahaman yang tinggi. Siswa yang mempunyai pemahaman yang rendah terhadap materi-materi ini dapat mengakibatkan siswa mengalami kesulitan dalam memahami materi redoks. Oleh karena itu diperlukan model pembelajaran yang sesuai dalam menyajikan materi ini agar tujuan pembelajaran dapat tercapai secara maksimal.

Berdasarkan nilai ulangan akhir semester gasal kelas $X$ diperoleh bahwa terdapat kelas yang mempunyai rata-rata nilai kelas yang rendah, yaitu kelas X.9 dengan nilai rata-rata 37,7. Materi pelajaran yang diujikan dalam ulangan semester merupakan materi yang berhubungan dengan materi redoks. Dengan demikian apabila nilai semester rendah maka diduga kelas tersebut memiliki masalah ketika menerima materi pelajaran redoks. Adapun rata-rata nilai ulangan akhir semester gasal kelas $\mathrm{X}$ terdapat pada Tabel 1.

Observasi yang dilakukan menunjukkan bahwa interaksi sosial yang terjalin antarsiswa di kelas X.9 yang berkemampuan tinggi, sedang, dan rendah belum terjalin dengan baik. Hal ini dibuktikan dengan hasil angket interaksi sosial pratindakan yaitu sebesar $47,37 \%$. Sebagian besar siswa masih mempunyai sifat individualisme yang tinggi dan masih kurang peduli satu dengan yang lainnya. Hal ini terlihat ketika diberikan tugas oleh guru, siswa yang berkemampuan tinggi tidak membimbing siswa lain dan siswa yang berkemampuan rendah tidak ada kemauan untuk bertanya kepada siswa yang berkemampuan lebih tinggi. 
Tabel 1. Rata-Rata Nilai Ulangan Akhir Semester Gasal Kelas X SMA Muhammadiyah Karanganyar Tahun Pelajaran 2015/2016

\begin{tabular}{cccc}
\hline Kelas & $\begin{array}{c}\text { Jumlah } \\
\text { Siswa }\end{array}$ & $\begin{array}{c}\text { Rata- } \\
\text { rata }\end{array}$ & $\begin{array}{r}\text { Ketuntas- } \\
\text { an }(\%)\end{array}$ \\
\hline X.1 & 22 & 56,45 & 9,09 \\
X.2 & 40 & 49,03 & 10,00 \\
X.3 & 39 & 42,90 & 7,69 \\
X.4 & 41 & 43,24 & 7,32 \\
X.5 & 42 & 42,30 & 7,14 \\
X.6 & 42 & 36,40 & 7,14 \\
X.7 & 44 & 39,30 & 6,82 \\
X.8 & 40 & 40,57 & 7,50 \\
X.9 & 38 & 37,76 & 5,26 \\
X.10 & 47 & 32,50 & 10,64 \\
X.11 & 40 & 28,75 & 10,00 \\
X.12 & 46 & 41,33 & 8,69 \\
X.13 & 42 & 39,58 & 9,52 \\
X.14 & 33 & 40,41 & 6,06 \\
\hline
\end{tabular}

UNESCO merumuskan empat pilar pendidikan untuk menghadapi dan menyesuaikan diri dengan perkembangan dunia yang sangat cepat, yaitu : (1) learning to know, belajar mengetahui, (2) learning to do, belajar berkarya, (3) learning to live together, belajar hidup bersama, dan (4) learning to be, belajar berkembang secara utuh. Salah satu pilar penting dari pendidikan tersebut adalah learning to live together. Tahap learning to live together mengembangkan pengertian atas diri orang lain dengan cara mengenali diri sendiri serta menghargai kesalingtergantungan, melaksanakan proyek bersama dan belajar mengatasi konflik dengan semangat menghargai nilai pluralitas, saling mengerti, dan perdamaian [4]. Penerapan learning to live together dalam proses pembelajaran dapat berupa interaksi sosial yang terjalin antarsiswa. Interaksi sosial dapat memberikan dukungan dan refleksi siswa yang berpengaruh terhadap proses dan hasil pembelajaran [5]. Dengan demikian sekolah bertanggungjawab penuh untuk membangun sikap sosial siswa dengan cara menerapkan komunikasi interpersonal dan keterlibatan kelompok di antara mereka.

Dari berbagai masalah di atas, perlu diadakan perbaikan kualitas interaksi sosial maupun prestasi belajar siswa. Sebagai tindak lanjut guna mengatasi permasalahan yang terjadi, maka perlu dilakukan penelitian tindakan (action research) yang berorientasi pada perbaikan kualitas pembelajaran melalui Penelitian Tindakan Kelas (PTK) atau Classroom Action Research (CAR). Tujuan PTK adalah untuk memperbaiki dasar pemikiran dan kepantasan dari praktikpraktik belajar mengajar, memperbaiki pemahaman dari praktik belajar mengajar, serta memperbaiki situasi atau lembaga tempat praktik tersebut dilakukan [6]. Dengan demikian dapat disimpulkan bahwa PTK merupakan pencermatan yang dilakukan oleh guru di dalam kelasnya sendiri melalui refleksi diri, dengan tujuan untuk memperbaiki profesinya sebagai guru, sehingga hasil belajar peserta didik terus meningkat.

Upaya yang dapat dilakukan oleh guru dalam rangka memperbaharui praktik pembelajaran adalah dengan penerapan model pembelajaran kooperatif. Pembelajaran kooperatif mengacu pada metode pembelajaran di mana siswa bekerjasama dalam kelompok kecil dan saling membantu dalam belajar. Berdasarkan permasalahan yang telah dipaparkan di atas, dibutuhkan model pembelajaran kooperatif yang tidak hanya meningkatkan interaksi sosial tetapi juga prestasi belajar siswa, salah satunya adalah dengan menggunakan model pembelajaran kooperatif tipe Team Assisted Individualization (TAI). Tujuan pembelajaran TAl adalah untuk mengatasi kesulitan pemahaman serta memecahkan permasalahan materi pembelajaran secara bersama dengan ketua kelompok (asisten) yang mempunyai pengetahuan yang lebih. Siswa yang berkemampuan lebih tinggi dapat membantu temannya yang mengalami kesulitan dalam belajar. Dengan demikian, pembelajaran TAI lebih mengacu pada kemampuan 
interaksi sosial yang baik antara semua komponen pengajaran, sehingga interaksi sosial antarsiswa dapat terjalin dengan baik dan dapat meningkatkan prestasi belajar. Penelitian tentang TAI yang telah dilakukan menyebutkan bahwa TAl merupakan metode yang efektif dalam pembelajaran sains. TAI juga berpotensi dapat memperbaiki prestasi belajar siswa dalam pembelajaran sains dasar [7].

Selain model pembelajaran, media pembelajaran merupakan salah satu komponen yang integral dalam sistem pembelajaran, artinya media menjadi komponen yang cukup penting dalam strategi penyampaian pembelajaran. Melihat fungsinya, bahan ajar memuat pesan-pesan pembelajaran yang siap untuk disampaikan kepada siswa maka dapat dikatakan bahwa bahan ajar termasuk media pembelajaran. Bahan ajar merupakan bahan-bahan atau materi pelajaran tertentu yang disusun secara sistematis dan ringkas supaya materi lebih mudah dipahami. Bahan ajar yang digunakan di SMA Muhammadiyah 1 Karanganyar dalam pembelajaran kimia berupa LKS yang disusun oleh MGMP Kabupaten Karanganyar. LKS tersebut berisi materi yang ringkas dan latihan soal dan merupakan satu-satunya bahan ajar yang digunakan. Dengan demikian, diperlukan bahan ajar lain sebagai penunjang pembelajaran yang memuat materi secara lengkap agar siswa menjadi mudah dalam memahami materi.

Adapun bahan ajar yang dimaksud dalam penelitian ini adalah modul yang berupa paket belajar dan meliputi serangkaian pengalaman belajar yang direncanakan dan dirancang secara sistematis untuk membantu siswa mencapai tujuan belajar. Modul pembelajaran yang baik harus mampu menyajikan materi ajar sesuai dengan tuntutan kurikulum, mengikuti perkembangan ilmu pengetahuan dan teknologi (IPTEK), dan dapat menjembatani pembelajaran agar kompetensi yang telah ditetapkan dapat tercapai. Penelitian sebelumya menyebutkan bahwa bahan ajar materi pokok konsep reaksi redoks disusun oleh peneliti dengan menggunakan konsep yang lebih sistematis dan ringkas supaya materi lebih mudah dipahami [8].

Berdasarkan uraian di atas, peneliti melakukan penelitian untuk meningkatkan interaksi sosial dan prestasi belajar siswa pada kelas X.9 SMA Muhammadiyah 1 Karanganyar dengan menggunakan model pembelajaran kooperatif tipe Team Assisted Individualization (TAl) berbantuan modul. Keunggulan dari pembelajaran TAl berbantuan modul adalah menerapkan pembelajaran kelompok yang berpusat pada siswa dan bimbingan antarteman dimana modul berperan sebagai penyedia informasi dasar, sebagai bahan pembelajaran bagi siswa, dan sebagai bahan pelengkap dengan ilustrasi dan foto yang komunikatif. Dengan demikian pembelajaran TAI berbantuan modul diharapkan mampu meningkatkan interaksi sosial dan prestasi belajar siswa.

\section{METODOLOGI PENELITIAN}

Penelitian ini merupakan Penelitian Tindakan Kelas (PTK) yang terdiri dari dua siklus. Subjek penelitian adalah siswa kelas X.9 SMA Muhammadiyah 1 Karanganyar yang berjumlah 38 siswa. Pemilihan subjek dalam penelitian ini didasarkan pada pertimbangan bahwa subjek tersebut mengalami permasalahan yang telah teridentifikasi pada saat observasi awal dan wawancara dengan guru dan siswa. Objek penelitian ini adalah interaksi sosial dan prestasi belajar siswa (aspek afektif dan kognitif) terhadap pembelajaran yang diterapkan.

Data yang dikumpulkan dalam penelitian ini meliputi data informasi tentang keadaan siswa dilihat dari aspek kualitatif dan kuantitatif. Aspek kualitatif berupa data hasil observasi, wawancara, dan pemberian angket yang menggambarkan proses pembelajaran di kelas. Aspek kuantitatif yang dimaksud adalah berupa data penilaian hasil belajar siswa pada 
materi redoks yang meliputi aspek kognitif dan afektif baik siklus I maupun siklus II.

Analisis data dalam Penelitian Tindakan Kelas (PTK) dmulai sejak awal sampai berakhirnya pengumpulan data. Data-data dari hasil penelitian di lapangan diolah dan dianalisis secara kualitatif. Analisis kualitatif yang dimaksud adalah analisis deskriptif. Teknik analisis juga mengacu pada model analisis Miles dan Huberman yang dilakukan dalam tiga komponen yaitu reduksi data, penyajian data, penarikan kesimpulan, dan verifikasi [9].

Teknik validitas data yang digunakan dalam penelitian ini adalah teknik triangulasi yaitu teknik pemeriksaan validitas data dengan memanfaatkan sarana dari luar data itu untuk keperluan pengecekan atau teknik pembandingan data itu. Teknik triangulasi data yang dilakukan berupa triangulasi metode pengumpulan data [10]. Dalam penelitian ini peneliti menggunakan metode pengumpulan data melalui teknik observasi, wawancara, dan angket.

\section{HASIL DAN PEMBAHASAN}

Berdasarkan masalah yang telah diidentifikasi sebelum tindakan, maka diperlukan model pembelajaran yang tepat untuk meningkatkan interaksi sosial dan prestasi belajar siswa pada kelas X.9 SMA Muhammadiyah 1 Karanganyar. Model pembelajaran yang digunakan adalah model pembelajaran kooperatif tipe Team Assisted Individualization (TAI) berbantuan modul pada materi pokok Reaksi Redoks. Tujuan pembelajaran TAI adalah untuk mengatasi kesulitan pemahaman serta memecahkan permasalahan materi pembelajaran secara bersama dengan ketua kelompok (asisten) yang mempunyai pengetahuan lebih. Siswa yang berkemampuan lebih tinggi dapat membantu temannya yang mengalami kesulitan dalam belajar. Dengan demikian, pembelajaran TAl lebih mengacu pada kemampuan interaksi sosial yang baik antara semua komponen pengajaran, sehingga interaksi sosial antarsiswa dapat terjalin dengan baik dan dapat meningkatkan prestasi belajar. Dengan demikian pembelajaran TAl berbantuan modul diharapkan mampu meningkatkan interaksi sosial dan prestasi belajar siswa.

\section{Siklus I}

Pada tahap perencanaan, peneliti bersama guru menyiapkan silabus, RPP, media pembelajaran, instrumen penelitian, dan merencanakan jadwal penelitian. Pembelajaran direncanakan terdiri dari 6 jam pelajaran (3 kali tatap muka) yaitu $4 \times 45$ menit untuk penyampaian materi dan $2 \times 45$ menit untuk tes evaluasi siklus $I$.

Berdasarkan perencanaan tindakan yang telah dilakukan oleh peneliti, kemudian diterapkan di kelas X.9 SMA Muhammadiyah 1 Karanganyar. Proses pembelajaran menggunakan model Team Assisted Individualization (TAI), siswa dibagi menjadi 8 kelompok dengan masingmasing kelompok beranggotakan 4-5 orang dengan salah satu anggota sebagai asisten. Kegiatan awal pembelajaran adalah guru memberikan apersepsi kepada siswa berupa pertanyaan yang berhubungan dengan kehidupan sehari-hari yang dikaitkan dengan materi yang akan diajarkan. Hal ini bertujuan untuk menggali pengetahuan awal siswa. Selanjutnya, guru memberikan orientasi dengan menyampaikan tujuan pembelajaran dan model pembelajaran yang akan digunakan pada pertemuan hari ini. Kemudian guru memberikan motivasi dengan menyampaikan manfaat mempelajari materi tersebut agar siswa bersemangat mengikuti pembelajaran.

$$
\text { Pada kegiatan inti, }
$$
pembelajaran dibagi menjadi tiga tahap, yaitu eksplorasi, elaborasi, dan konfirmasi yang disesuaikan dengan sintaks model pembelajaran TAI. Pada tahap eksplorasi, guru memfasilitasi terjadinya interaksi antarsiswa dengan guru, lingkungan, dan sumber belajar lainnya pada pokok bahasan reaksi 
redoks (teaching group). Selain itu, siswa mencari informasi tentang materi reaksi redoks dengan membaca modul yang telah dipersiapkan oleh guru (student creative). Pada tahap elaborasi, siswa berdiskusi dalam kelompok tentang permasalahan berupa soal diskusi yang terdapat di dalam modul (team study). Selanjutnya siswa menyajikan hasil diskusi kelompok di depan kelas dan siswa dari kelompok lain menanggapi presentasi tersebut dengan cara memberi pertanyaan atau masukan kepada kelompok tersebut (whole class unit). Pada tahap konfirmasi, guru memberikan penguatan dan umpan balik positif dalam bentuk lisan maupun tulisan tentang hasil pembelajaran yang telah berlangsung. Hal ini dilakukan dengan tujuan supaya tidak terjadi miskonsepsi mengenai materi yang didiskusikan. Pada kegiatan akhir, guru membimbing siswa untuk menyampaikan kesimpulan dari pembelajaran yang telah dilakukan. Tahap selanjutnya guru memberikan post test kepada siswa yang dikerjakan secara individu sebagai evaluasi (fact test).

Pada akhir siklus I dilakukan tes interaksi sosial, tes aspek afektif, dan tes aspek kognitif. Hasil tes interaksi sosial diperoleh persentase ketuntasan sebesar $71,05 \%$. Hasil tes aspek afektif diperoleh presentase ketuntasan siswa kelas X.9 adalah $81,58 \%$. Penilaian untuk aspek kognitif diperoleh persentase ketuntasan 34,21\%. Ketercapaian masing-masing aspek pada siklus I disajikan dalam Tabel 2.

Berdasarkan keseluruhan hasil yang diperoleh pada siklus I, terdapat dua indikator pada aspek kognitif yang belum mencapai target yang telah ditentukan, yaitu menentukan bilangan oksidasi atom unsur dalam senyawa atau ion dan menentukan oksidator dan reduktor dalam reaksi redoks. Belum tercapainya kedua indikator tersebut disebabkan karena materi pada indikator tersebut membutuhkan pemahaman konsep yang mendalam dalam menentukan bilangan oksidasi dan menghitung bilangan oksidasi serta mengidentifikasi perubahannya. Selain itu, peran asisten yang belum maksimal juga menjadi salah satu faktor penyebab rendahnya ketercapaian indikator tersebut. Oleh karena itu, peneliti perlu mengadakan tindakan lebih lanjut yaitu dengan melakukan pembelajaran di siklus II.

\begin{tabular}{|c|c|c|}
\hline bel & $\begin{array}{l}\text { Ketercapaia } \\
\text { Keberhasilaı }\end{array}$ & $\begin{array}{l}\text { Target } \\
\text { Siklus I }\end{array}$ \\
\hline Aspek & $\begin{array}{c}\text { Ketercapaian } \\
(\%)\end{array}$ & Kriteria \\
\hline $\begin{array}{l}\text { Interaksi } \\
\text { Sosial }\end{array}$ & 71,05 & apai \\
\hline $\begin{array}{l}\text { Aspek } \\
\text { Afektif }\end{array}$ & 81,58 & Tercapai \\
\hline $\begin{array}{l}\text { Aspek } \\
\text { Kognitif }\end{array}$ & 34,21 & $\begin{array}{l}\text { Belum } \\
\text { Tercapai }\end{array}$ \\
\hline
\end{tabular}

Siklus II

Berdasarkan hasil refleksi tindakan siklus I maka dilakukan perencanaan untuk pelaksanaan tindakan pada siklus II. Proses pembelajaran dilakukan perbaikan dengan beberapa perubahan perlakuan, salah satunya yaitu mengubah kelompok diskusi. Penentuan kelompok diskusi berdasarkan hasil tes kognitif siklus I dan pertimbangan guru. Perubahan asisten dan anggota kelompok pada siklus II diharapkan dapat meningkatkan prestasi belajar pada aspek kognitif siswa dalam mencapai target yang telah ditentukan. Pada pembelajaran siklus II difokuskan pada indikator kompetensi yang belum tercapai. Guru mengulang kembali indikator kompetensi pada aspek kognitif yang belum tuntas, yaitu menentukan bilangan oksidasi atom unsur dalam senyawa atau ion dan menentukan oksidator dan reduktor dalam reaksi redoks. Pembagian kelompok pada siklus II didasarkan pada hasil evaluasi pada siklus I. Siswa yang sudah tuntas pada siklus I didistribusikan ke dalam kelompokkelompok untuk menjadi asisten dan membantu siswa lain di dalam kelompok. Jumlah kelompok pada siklus II sama dengan siklus I yaitu terdiri dari 8 kelompok dan setiap kelompok terdiri dari 4-5 siswa. Hal ini 
disesuaikan dengan sintaks pada model pembelajaran kooperatif tipe TAl.

Pelaksanaan tindakan siklus II dilakukan satu kali pertemuan, dengan alokasi waktu 1 x 60 menit untuk pelaksanaan pembelajaran dan $1 \times 30$ menit untuk kegiatan evaluasi siklus II. Pada pembelajaran siklus II, guru hanya menyampaikan materi sesuai dengan indikator yang belum tuntas pada siklus I. Tes kognitif diujikan pada akhir pembelajaran siklus II yang berbentuk tes objektif sebanyak 10 butir soal. Berdasarkan analisis hasil tes aspek kognitif siklus II diperoleh hasil bahwa siswa kelas X.9 yang telah mencapai ketuntasan sebanyak $65,79 \%$. Dari persentase ketuntasan tersebut, maka hasil tes siklus II untuk aspek kognitif telah memenuhi target ketuntasan yang telah ditetapkan yaitu sebesar $60 \%$. Persentase ketuntasan aspek kognitif pada siklus II ditunjukkan pada Gambar 1.

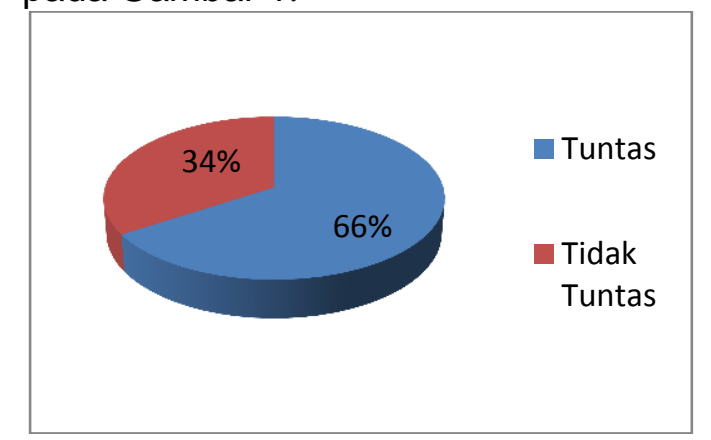

Gambar 1. Diagram Pie Ketuntasan Aspek Kognitif Siklus II

\section{Perbandingan Antarsiklus}

Perbandingan hasil tindakan antar siklus ini bertujuan untuk mengetahui peningkatan yang terjadi selama tindakan siklus I dan siklus II. Perbandingan hasil tindakan hanya dilakukan pada aspek kognitif karena aspek afektif dan interaksi sosial telah mencapai target yang ditentukan pada siklus I. Perbandingan antar siklus disajikan dalam Tabel 3.

Penelitian tindakan kelas dapat dikatakan berhasil apabila target yang ditentukan dapat tercapai. Penelitian ini dapat disimpulkan berhasil karena telah mencapai target dari aspek interaksi sosial dan prestasi belajar yang mencakup aspek afektif dan kognitif. Hasil tindakan dan pembahasan dapat disimpulkan bahwa pembelajaran model TAl berbantuan modul dapat meningkatkan interaksi sosial dan prestasi belajar siswa pada materi pokok reaksi redoks kelas X.9 SMA Muhammadiyah 1 Karanganyar tahun pelajaran 2015/2016.

Tabel 3. Perbandingan Hasil Tindakan Antar Siklus Materi Reaksi Redoks SMA Muhammadiyah 1 Karanganyar Tahun Pelajaran 2015/2016

\begin{tabular}{llll}
\hline Aspek & \multicolumn{2}{l}{ Capaian (\%) } & Kriteria \\
\cline { 2 - 3 } & Siklus & Siklus & \\
& I & II & \\
\hline Kognitif & 34,21 & 65,79 & Tercapai
\end{tabular}

\section{KESIMPULAN}

Model pembelajaran kooperatif Team Assisted Individualization (TAI) berbantuan modul dapat meningkatkan interaksi sosial dan prestasi belajar siswa pada materi pokok reaksi redoks kelas X.9 SMA Muhammadiyah 1 Karanganyar tahun pelajaran 2015/2016.

\section{UCAPAN TERIMAKASIH}

Terima kasih peneliti ucapkan kepada Dra. Nuryati selaku guru mata pelajaran Kimia SMA Muhammadiyah 1 Karanganyar, siswa kelas X.9 SMA Muhammadiyah 1 Karanganyar, serta seluruh pihak yang turut berperan dalam penelitian ini.

\section{DAFTAR RUJUKAN}

[1] Halimah, L. (2009). Jurnal Penelitian, 10 (2), 1-18.

[2] Chayati, N, Ashadi, \& Utomo, S.B. (2015).. Jurnal Pendidikan Kimia, 4 (4), 1-7.

[3] Permendikbud RI, Nomor 59. (2014). Kurikulum 2013 untuk SMA/MA.

[4] Febriana, B.W., Ashadi, \& Masykuri, M. (2013). Pengembangan Modul Kimia Berbasis Problem Based Learning (PBL) pada Materi 
Senyawa Hidrokarbon dan

Turunannya Kelas XI SMK

Kesehatan Ngawi. Tesis Tidak

Dipublikasikan. Universitas

Sebelas Maret, Surakarta.

[5] Wang, H. (2005). International Journal of Technology in Teaching and Learning, 1 (2), 79-

88.

[6] Suyadi. (2010). Panduan Penelitian Tindakan Kelas.

Yogyakarta: Diva Press.

[7] Nneji, L. (2011). Knowledge Review, 23 (4), 1-8.

[8] Imaduddin, M. (2013).. Jurnal Pendidikan Sains, 01 (01), 26-36.

[9] Miles, M. B. \& Huberman, A. M. (1995). Analisis Data Kualitatif. Terj. Rohendi. Jakarta: UI Press.

[10] Moeleong J. L. (1995). Metodologi Penelitian Kualitatif. Bandung: Remaja Rosdakarya. 